\title{
Drought susceptibility and recovery of transplanted Quercus rubra seedlings in relation to root system morphology
}

\author{
Douglass F. JACOBS*, K. Francis SALIFU, Anthony S. DAVIS \\ Hardwood Tree Improvement and Regeneration Center, Department of Forestry and Natural Resources, Purdue University, \\ West Lafayette, IN 47907-2061, USA
}

(Received 1 December 2008; revised version 2 February 2009; accepted 22 February 2009)

Keywords: gas exchange / northern red oak / root growth / transplant shock / xylem water potential

Mots-clés :

échanges gazeux / chêne rouge / croissance racinaire / choc de transplantation / potentiel hydrique xylémique

\begin{abstract}
- Transplant shock, implicated by depressed seedling physiological status associated with moisture stress immediately following planting, limits early plantation establishment. Large root volume $(R v)$ has potential to alleviate transplant shock because of higher root growth potential and greater access to soil water.

- We investigated impacts of drought and transplant $R v$ on photosynthetic assimilation $(A)$, transpiration $(E)$, stomatal conductance $\left(g_{\mathrm{s}}\right)$, predawn leaf xylem water potential $\left(\Psi_{\mathrm{L}}\right)$, and growth of northern red oak (Quercus rubra L.) seedlings to explain mechanisms associated with susceptibility to transplant shock. One year-old barerooot seedlings were graded into four $R v$ categories and either well watered or subjected to drought consisting of low, medium, or high moisture stress by discontinuing irrigation at 22-day intervals for 3 months. Thereafter, all treatments were re-watered to examine recovery.

- Transplant shock was signified by reduced $A, E, g_{\mathrm{s}}$, and $\Psi_{\mathrm{L}}$, which generally increased with increasing moisture stress and $R v$. Physiological status improved during recovery, though stress was still evident in seedlings exposed to medium or high moisture stress and in larger $R v$ seedlings. Growth declined with increasing moisture stress but was generally similar among $R v$ treatments, likely reflecting greater $A$ at the whole plant level and/or reliance upon stored reserves in large $R v$ seedlings.

- The most effective drought avoidance mechanisms were root growth, stomatal regulation, reduced leaf area, and higher growth allocation to roots relative to shoots. Our results suggest that large initial $R v$ does not enhance drought avoidance during the first season after transplant in northern red oak seedlings.
\end{abstract}

Résumé - Sensibilité à la sécheresse et reprise des semis transplantés de Quercus rubra en relation avec la morphologie racinaire.

- Le choc de transplantation, lié à l'état physiologique déprimé des plants associé à un stress hydrique, immédiatement après la plantation, limite le début de l'installation des plants. Un important volume racinaire $(R v)$ a le potentiel d'atténuer le choc de transplantation en raison du fort potentiel de croissance racinaire et d'un meilleur accès à l'eau du sol.

Nous avons étudié les impacts de la sécheresse et des transplants $R v$ sur l'assimilation photosynthétique $(A)$, la transpiration $(E)$, la conductance stomatique $\left(g_{\mathrm{s}}\right)$, le potentiel hydrique de base $\left(\Psi_{\mathrm{L}}\right)$, et la croissance des plants de chêne rouge (Quercus rubra L.) pour expliquer les mécanismes associés à la sensibilité à un choc de transplantation. Des plants de un an à racines nues ont été classés en quatre catégories $R v$ et soit bien arrosés, ou soumis à une sécheresse, consistant à un faible, moyen ou fort stress hydrique en cessant l'irrigation à 22 jours d'intervalle(27, 49 et 72 après la transplantation) pour 3 mois. Par la suite, tous les traitements ont été arrosés afin d'examiner la reprise.

- Le choc de transplantation qui généralement a augmenté avec l'augmentation du stress hydrique et $R v$, a été significatif par la réduction de $A, E, g_{\mathrm{s}}$, and $\Psi_{\mathrm{L}}$. L'état physiologique s'est amélioré lors de la reprise, même si le stress est encore évident chez les plants exposés à un stress hydrique moyen ou élevé et chez les plants à $R v$ les plus importants. La croissance a diminué avec l'augmentation du stress hydrique, mais elle a été généralement similaire chez les traitements $R v$, reflétant probablement une plus grande $A$ au niveau du plant entier et / ou le recours à des réserves stockées dans les plants à $R v$ important.

\footnotetext{
*Corresponding author: djacobs@purdue.edu
} 
- Les mécanismes d'évitement de la sécheresse les plus efficaces ont été la croissance des racines, la régulation stomatique, une surface foliaire réduite et une allocation de la croissance plus élevée aux racines par rapport aux pousses. Nos résultats suggèrent que les grandes $R v$ initiales n'améliorent pas l'évitement de la sécheresse durant la première saison après transplantation chez les plants de chêne rouge.

\section{INTRODUCTION}

Northern red oak (Quercus rubra L.) is a dominant component of eastern hardwood forests in North America and a valuable landscape species with moderate to fast growth rates (Sander, 1990). Northern red oak grows from Cape Breton Island, Nova Scotia, Prince Edward Island, New Brunswick, Gaspé Peninsula of Quebec, to Ontario; from Minnesota south to eastern Nebraska and Oklahoma; east to Arkansas, southern Alabama, Georgia, and North Carolina (Sander, 1990). Detailed discussion on northern red oak habitat, life history, and genetics can be found in Sander (1990). Most artificial forest regeneration projects involving northern red oak use $1+0$ or $2+0$ bareroot seedlings for field planting (Jacobs et al., 2004b). These seedlings undergo significant transplant shock following planting, which may be associated with loss of fine root structure during nursery lifting (Struve, 1990; Struve and Joly, 1992).

Transplant shock (i.e., planting check, planting shock) is an interruption in the normal physiology of a seedling after planting that results in stunted growth or reduction of foliage, and if severe, mortality (Burdett, 1990). The major cause of transplant shock is water deficit due to restricted uptake of water at planting because of temporary impairment of seedling root function or poor initial root-soil contact (Burdett, 1990; Burdett et al., 1984). Severe planting check may limit plantation productivity by depressing photosynthetic assimilation (A) and putting planted stock at a disadvantage in competition with non-crop vegetation (Burdett, 1990; Haase and Rose, 1993). This phenomenon has accounted for plantation failures of white spruce (Picea glauca (Moench) Voss), Engelmann spruce (Picea engelmannii Parry), or a natural hybrid of these species in Canada (Vyse, 1981) and Douglas-fir (Pseudotsuga menziesii (Mirb.) Franco) in northwestern California (Waters et al., 1991). Seedling physiological responses, such as reduced $A$, transpiration $(E)$, stomatal conductance $\left(g_{\mathrm{s}}\right)$, and leaf xylem water potential $\left(\Psi_{\mathrm{L}}\right)$ implicate planting shock (Blake, 1983; Grossnickle, 1988). Plant morphological indicators of planting shock include reduced leaf area, restricted shoot growth, shortened needles, and a greater number of needles per unit of leader (Haase and Rose, 1993; Struve and Joly, 1992).

Drought resistance of plants may be divided into either drought tolerance (i.e., physiological and biochemical adaptations that permit plant function under water shortage) or drought avoidance (i.e., developmental and morphological changes that limit water shortages) (Levitt, 1972). Drought tolerance mechanisms may involve turgor maintenance (by accumulation of solutes) and/or desiccation tolerance (by protoplasmic resistance) (Jones et al., 1981). Drought avoidance permits a plant to maintain tissue water contents near optimum levels during periods of low soil moisture availability and high atmospheric evaporative demand (Levitt, 1972). The two main drought avoidance mechanisms are stomatal closure and increased root growth relative to shoots (Johnson et al., 1984). Hence, plants may respond to drought by closing stomata to conserve tissue water, which could prevent lethal desiccation, but results in decreased $A$ (Burdett, 1990). Alternatively, moisture stress may be alleviated by root growth, which enhances water absorption by increasing the surface area of permeable unsuberized roots and providing access to a larger volume of soil (Burdett, 1990; Sands, 1984). In addition, the expansive forces exerted by growing roots improve root-soil contact (Burdett, 1990).

It has been argued that large root volume $(R v)$ of bareroot seedlings at transplanting may act to confer drought avoidance that alleviates transplant shock because of greater root growth potential and access of larger $R v$ to soil resources (Carlson, 1986; Carlson and Miller, 1990; Haase and Rose, 1993; Jacobs et al., 2004a). However, large $R v$ is often correlated with large shoots, and the transpirational demand after budbreak coupled with insufficient water uptake may result in higher water deficits (Sands, 1984), which could induce transplant shock detrimental to field performance of seedlings. Consequently, seedling field survival and growth may depend on ability to mitigate internal water deficits and/or resist drought (Grossnickle, 2005; Struve and Joly, 1992), especially for northern red oak, which is generally restricted to relatively mesic sites (Sander, 1990).

Although evidence suggests that transplant shock may limit early plantation productivity (Vyse, 1981; Waters et al., 1991), relatively little research has been conducted to examine the physiological and morphological mechanisms involved (Haase and Rose, 1993). It has been demonstrated that seedlings with larger initial $R v$ have higher root growth potential (Carlson, 1986), tend to better tolerate transplant shock over time (Haase and Rose, 1993), and may have more rapid early growth rates (Rose et al., 1991a; 1991b; Jacobs et al., 2005). Additionally, root system morphology partly explained establishment success of some deciduous hardwood species (Struve, 1990; Jacobs et al., 2005). Therefore, a better understanding of root system development and its response to a set of limiting site conditions, such as water deficits, is essential. This knowledge can be used to help match specific seedling types to site conditions under which transplanting will have a high probability of field success. To contribute towards this understanding, we exposed seedlings with varied root volumes under controlled environmental conditions to drought ranging from well-watered to high moisture stress by periodically discontinuing irrigation at 22-day intervals for 3 months. Subsequently, all treatments were re-watered for another 2 months. 
The first phase examined seedling responses to drought, while the second evaluated ability of plants to recover from induced drought. Therefore, the focus of our research was to assess the impact of drought and initial seedling $R v$ on plant physiological and morphological responses to explain underlying mechanisms that enable northern red oak seedlings to withstand transplant shock. This was accomplished by periodically evaluating gas exchange, water relations, and growth during the study. Specifically, our objectives were to determine (i) the influence of $R v$ on $A, E, g_{\mathrm{s}}$, and $\Psi_{\mathrm{L}}$ associated with moisture stress, (ii) the physiological ability of northern red oak seedlings to recover after water stress is alleviated, and (iii) the role of increased root growth as an important mechanism to explain drought avoidance in northern red oak seedlings.

\section{MATERIALS AND METHODS}

\subsection{Cultural conditions and experimental treatments}

Bareroot northern red oak seedlings were grown under standard operational conditions, detailed in Jacobs (2003), at the Indiana Department of Natural Resources Vallonia State Tree Nursery in southwestern Indiana, USA ( $\left.38^{\circ} 48^{\prime} \mathrm{N}, 86^{\circ} 06^{\prime} \mathrm{W}\right)$. Seeds were sown in November 2000 and seedlings were grown until lifting in December 2001. Seedlings were operationally graded, packaged, and stored at $2{ }^{\circ} \mathrm{C}$ until transported to a lab at Purdue University in March 2002 for sorting. A total of 128 randomly selected seedlings were washed free of soil, tagged, and measured for stem height (root collar to base of terminal bud), stem diameter $(1 \mathrm{~cm}$ above root collar), fresh mass, number of first-order lateral roots (FOLR; i.e. number of permanent, FOLR $>1 \mathrm{~mm}$ diameter at junction with taproot), and $R v$ using water displacement (Jacobs et al., 2005).

Seedlings were sorted into $4 R v$ categories $(\mathrm{RvC})$ for the study (Tab. I). On 17 May 2002, 32 seedlings from each RvC treatment were transplanted into $12.04 \mathrm{~L}$ pots $(22.7 \mathrm{~cm}$ width $\times 39.4 \mathrm{~cm}$ depth). Use of relatively large containers was intended to more accurately simulate potential field conditions. Pots contained a medium of 8:5:2:2:3 (v:v:v:v:v) composted pine bark:coconut coir:bark ash:perlite:peat (Metro-Mix ${ }^{\circledR} 560$, Scotts Co., Marysville, OH, USA). Pots were placed on a greenhouse bench (mean daytime temperature $24{ }^{\circ} \mathrm{C}$ and $20{ }^{\circ} \mathrm{C}$ at night) in the Department of Horticulture Plant Growth Facility at Purdue University $\left(40^{\circ} 25^{\prime} \mathrm{N}, 86^{\circ} 55^{\prime} \mathrm{W}\right)$. Following transplant, the medium in all treatments was watered to field capacity and pots were well watered for the first $27 \mathrm{~d}$ to induce flushing and simulate high moisture availability typical of conditions soon after spring planting. Thereafter, eight seedlings from each $\mathrm{RvC}$ were randomly assigned to each of four moisture stress treatments. The well-watered (WW) control treatment received irrigation to field capacity approximately every $5 \mathrm{~d}$ throughout the experiment. The other three treatments consisted of eliminating the aforementioned irrigation regime 27,49 , or $71 \mathrm{~d}$ after transplant to induce high moisture stress (HMS), medium moisture stress (MMS), and low moisture stress (LMS), respectively.

On 9 September ( $115 \mathrm{~d}$ after transplant), the medium of plants in all moisture stress treatments was re-watered to field capacity, and pots were then well watered throughout the duration of the experiment (i.e., until 15 November, $182 \mathrm{~d}$ after transplant) to examine drought recovery. Supplemental lighting (about $140 \mu \mathrm{mol} \mathrm{m} \mathrm{m}^{-2} \mathrm{~s}^{-1}$ for
Table I. Range, mean, and standard error (SE) of initial seedling morphological parameters sorted according to four root volume categories $(\mathrm{RvC})(n=32)$.

\begin{tabular}{|c|c|c|c|c|}
\hline \multirow{3}{*}{ Parameter } & \multicolumn{4}{|c|}{ Initial seedling data } \\
\hline & \multicolumn{2}{|c|}{ Range } & \multirow{2}{*}{${ }^{\dagger}$ Mean } & \multirow{2}{*}{ SE } \\
\hline & Min & $\operatorname{Max}$ & & \\
\hline \multicolumn{5}{|c|}{ Root volume $\left(\mathrm{cm}^{3}\right)$} \\
\hline $\mathrm{RvC1}$ & 7 & 22 & $17 \mathrm{c}$ & 1.2 \\
\hline $\mathrm{RvC2}$ & 23 & 32 & $27 \mathrm{bc}$ & 0.8 \\
\hline $\mathrm{RvC3}$ & 31 & 46 & $39 b$ & 1.0 \\
\hline $\mathrm{RvC4}$ & 48 & 132 & $72 \mathrm{a}$ & 7.2 \\
\hline \multicolumn{5}{|c|}{ Fresh mass (g) } \\
\hline $\mathrm{RvC1}$ & 10 & 33 & $24 \mathrm{c}$ & 2.0 \\
\hline $\mathrm{RvC2}$ & 28 & 47 & $37 \mathrm{bc}$ & 1.5 \\
\hline $\mathrm{RvC3}$ & 38 & 75 & $53 \mathrm{~b}$ & 2.4 \\
\hline $\mathrm{RvC} 4$ & 65 & 195 & $105 \mathrm{a}$ & 10 \\
\hline \multicolumn{5}{|c|}{ Diameter (mm) } \\
\hline $\mathrm{RvC1}$ & 4 & 6 & $4 \mathrm{c}$ & 0.1 \\
\hline $\mathrm{RvC2}$ & 4 & 7 & $5 b$ & 0.2 \\
\hline $\mathrm{RvC} 3$ & 5 & 7 & $6 b$ & 0.2 \\
\hline $\mathrm{RvC4}$ & 6 & 11 & $8 a$ & 0.3 \\
\hline \multicolumn{5}{|c|}{ Height (cm) } \\
\hline $\mathrm{RvC1}$ & 20 & 51 & $34 \mathrm{c}$ & 2.0 \\
\hline $\mathrm{RvC2}$ & 21 & 66 & $38 \mathrm{bc}$ & 4.0 \\
\hline $\mathrm{RvC3}$ & 29 & 87 & $49 \mathrm{ab}$ & 4.0 \\
\hline $\mathrm{RvC4}$ & 28 & 87 & $60 \mathrm{a}$ & 5.0 \\
\hline \multicolumn{5}{|c|}{ First order lateral roots } \\
\hline $\mathrm{RvC1}$ & 1 & 8 & $5 c$ & 0.5 \\
\hline $\mathrm{RvC2}$ & 3 & 11 & $7 \mathrm{bc}$ & 0.6 \\
\hline $\mathrm{RvC3}$ & 4 & 15 & $10 \mathrm{ab}$ & 0.8 \\
\hline $\mathrm{RvC4}$ & 6 & 19 & $12 \mathrm{a}$ & 1.0 \\
\hline
\end{tabular}

$\uparrow$ Column means followed by different letters within $\mathrm{RvC}$ for each parameter differ significantly according to Tukey's HSD test $P<0.05$.

$16 \mathrm{~h} \mathrm{~d}^{-1}$ ) was installed at time of re-watering to help maintain growth during the period of seasonal daylength decline. The experiment was arranged as a completely randomized design with factorial treatments ( $4 \mathrm{RvC} \times 4$ moisture stress levels). Pots were re-arranged each month throughout the experiment to alleviate potential environmental variation associated with bench position.

\subsection{Measurements}

On 9 September, half of the seedlings (4 per treatment) were randomly selected, and harvested to examine the impact of drought on morphological development. The remaining plants were harvested at the end of the study (15 November). Seedlings were excavated from pots, washed free of media, and measured for stem height, stem diameter, fresh mass, FOLR, $R v$, number of leaves, and leaf area (Model 
LI-2000, Li-Cor, Inc., Lincoln, NE, USA). Seedlings were then ovendried at $70{ }^{\circ} \mathrm{C}$ for $72 \mathrm{~h}$ and weighed.

Gas exchange measurements included $A, E$, and $g_{\mathrm{s}}$ at weekly intervals during the period 23 August (98 d after transplant and $27 \mathrm{~d}$ since discontinuation of LMS irrigation) through 26 September and bi-weekly from 26 September through 25 October. Gas exchange was measured using an infrared gas analyzer (Model LCA-3, Analytical Development Corporation, Hoddesdon, UK) between 1 100-1 $300 \mathrm{~h}$ solar time. Measurements were taken during clear, sunny days. An external light source of approximately $1200 \mu \mathrm{mol} \mathrm{m} \mathrm{m}^{-2} \mathrm{~s}^{-1}$ was used to stabilize photosynthetically active radiation to minimize variation associated with light availability. Ambient $\mathrm{CO}_{2}$ was drawn into the leaf chamber from a height of $3 \mathrm{~m}$. Leaf temperature within the leaf chamber ranged from $26-27{ }^{\circ} \mathrm{C}$ and the sampled leaf always filled the $6.25 \mathrm{~cm}^{2}$ leaf chamber. At each measurement, a single representative leaf was sampled from the flush prior to the current growth flush and measurements were recorded after about 1 min when readings stabilized. Measurements were conducted on five seedlings per treatment during the first two samplings, and four plants in subsequent samplings. Pre-dawn leaf xylem water potential was measured bi-weekly from 23 August until 19 September and a month thereafter. Measurements of $\Psi_{\mathrm{L}}$ were determined using a Scholander pressure chamber (Model 600, PMS Instruments, Inc., Corvallis, OR, USA) and always occurred the day following gas exchange measurements and were conducted on the same leaf used for gas exchange.

\subsection{Statistical analysis}

Analysis of variance (ANOVA) was conducted on all measured physiological and morphological variables using SAS and where appropriate significant means were ranked according to Waller-Ducan's multiple range tests at $\alpha=0.05$. The Anderson and McLean's (1974) linear model was used for the ANOVA and is given as:

$$
Y_{\mathrm{ijk}}=\mu+M_{\mathrm{i}}+R v_{\mathrm{j}}+M R v_{\mathrm{ij}}+\varepsilon_{(\mathrm{ij}) \mathrm{k}}
$$

where $Y_{\mathrm{ijk}}$ is seedling physiological or morphological attribute estimated from the $k$ th replicate $(k=1,2,3,4)$, from the $j$ th $\operatorname{RvC}(j=1$, $2,3,4)$, and the $i$ th moisture regime $(i=1,2,3,4) ; \mu=$ overall mean; $M_{\mathrm{i}}=$ fixed effect of the ith moisture regime; $R v_{\mathrm{j}}=$ fixed effect of the $j$ th $\mathrm{RvC}$; followed by moisture by $R v$ interaction effects $M R v_{\mathrm{ij}}$ and $\varepsilon$ is error associated with measured seedling physiological or morphological attribute from replicates. The ANOVA tables associated with the linear model are shown in Tables II and III.

\section{RESULTS}

\subsection{Initial seedling morphological characteristics}

Seedlings were graded into $4 \mathrm{RvC}$ based on 25 percentiles of the population (Tab. I). Thus, treatments were designated as $\mathrm{RvC} 1\left(17 \mathrm{~cm}^{3} \pm 1.2\right)($ mean $\pm \mathrm{SE}), \operatorname{RvC} 2\left(27 \mathrm{~cm}^{3} \pm 0.8\right)$, $\mathrm{RvC} 3\left(39 \mathrm{~cm}^{3} \pm 1.0\right)$, and $\mathrm{RvC} 4\left(72 \mathrm{~cm}^{3} \pm 7.2\right)$ and differed significantly $(P<0.0001)$. Generally, seedlings with larger $R v$ were associated with greater plant fresh mass, stem diameter, height, and number of FOLR. For example, seedling fresh mass, diameter, and height were 338, 100, and $77 \%$ greater in
Table II. Analysis of variance associated with photosynthetic assimilation $(A)$, transpiration rate $(E)$, stomatal conductance $\left(g_{\mathrm{s}}\right)$, and predawn leaf xylem water potential $\left(\Psi_{\mathrm{L}}\right)$ as influenced by moisture stress $(M)$ induced by drought and initial root volume $(R v)$. (Error degrees of freedom $=48$ ).

\begin{tabular}{lccccc}
\hline \multirow{2}{*}{ Sampling date } & \multirow{2}{*}{ Source of variation } & \multicolumn{4}{c}{$P>F$} \\
\cline { 3 - 6 } & & $A$ & $E$ & $g_{\mathrm{s}}$ & $\Psi_{\mathrm{L}}^{\dagger}$ \\
\hline 23 -Aug & & 0.0001 & 0.0010 & 0.0002 & 0.0008 \\
& $R v$ & 0.0021 & 0.4748 & 0.7390 & 0.0001 \\
& $M \times R v$ & 0.0014 & 0.0061 & 0.0033 & 0.0109
\end{tabular}

4 -Sept

$\begin{array}{ccccc}M & 0.0001 & 0.0001 & 0.0001 & 0.0001 \\ R v & 0.0395 & 0.0077 & 0.0394 & 0.0001 \\ M \times R v & 0.0470 & 0.0418 & 0.0587 & 0.0146\end{array}$

12 -Sept

$\begin{array}{ccccc}M & 0.0001 & 0.0001 & 0.0001 & - \\ R v & 0.0050 & 0.0042 & 0.0295 & - \\ M \times R v & 0.1856 & 0.4506 & 0.7066 & -\end{array}$

19 -Sept

$\begin{array}{ccccc}M & 0.0001 & 0.0001 & 0.0001 & 0.1664 \\ R v & 0.0052 & 0.0665 & 0.0209 & 0.0037 \\ M \times R v & 0.3236 & 0.1638 & 0.3418 & 0.6411\end{array}$

$26-$ Sept

$\begin{array}{ccccc}M & 0.0001 & 0.0001 & 0.0001 & - \\ R v & 0.0001 & 0.0001 & 0.0001 & - \\ M \times R v & 0.2272 & 0.0502 & 0.0762 & -\end{array}$

$10-$ Oct

$\begin{array}{ccccc}M & 0.0001 & 0.0001 & 0.0001 & - \\ R v & 0.0001 & 0.0001 & 0.0001 & - \\ M \times R v & 0.0323 & 0.1379 & 0.0333 & -\end{array}$

$25-$ Oct

\begin{tabular}{ccccc}
$M$ & 0.0029 & 0.0001 & 0.0006 & 0.1540 \\
$R v$ & 0.0156 & 0.0162 & 0.0109 & 0.0074 \\
$M \times R v$ & 0.4221 & 0.9214 & 0.7990 & 0.7056 \\
\hline
\end{tabular}

$\dagger$ - Not determined.

RvC4 compared with RvC1 $(P<0.0001)$. Additionally, RvC4 plants had about $326 \%$ more fresh mass and were about $100 \%$ taller than $\mathrm{RvC} 1$ seedlings prior to transplant.

\subsection{Seedling physiological responses to drought}

For clarity, the experiment consisted of drought and recovery phases (Figs. 1-5 and Tab. III). The drought phase examined plant responses to moisture stress from 23 August through 9 September (i.e., 98-115 days after transplant; 2744, 49-66, and 71-88 days after discontinuation of irrigation for the LMS, MMS, and HMS treatments, respectively). The recovery phase examined plant recovery from drought during 
Table III. Analysis of variance testing effects of moisture stress $(M)$ induced by drought and root volume $(R v)$ on northern red oak seedling growth response under greenhouse environments. (Error degrees of freedom $=48$.)

\begin{tabular}{|c|c|c|c|c|c|c|c|c|}
\hline \multirow{2}{*}{ Sampling phase } & \multirow{2}{*}{ Source of variation } & \multicolumn{7}{|c|}{$P>F$} \\
\hline & & Root volume & Fresh mass & Diameter & Height & Lateral roots & Dry mass & $\#$ of leaves ${ }^{\dagger}$ \\
\hline \multicolumn{9}{|l|}{ Drought } \\
\hline & $R v$ & 0.7661 & 0.1109 & 0.9834 & 0.0076 & 0.1849 & 0.0001 & 0.0001 \\
\hline & $M \times R v$ & 0.0037 & 0.0006 & 0.1092 & 0.5153 & 0.0378 & 0.1339 & 0.2472 \\
\hline \multicolumn{9}{|l|}{ Recovery } \\
\hline & $R v$ & 0.4193 & 0.2116 & 0.3102 & 0.0002 & 0.6411 & 0.6411 & - \\
\hline & $M \times R v$ & 0.1396 & 0.0561 & 0.0478 & 0.2976 & 0.3813 & 0.3813 & - \\
\hline
\end{tabular}

$\dagger$ - Not determined.

the period 10 September through 25 October (i.e., 116-161 days after transplant) following resumption of irrigation.

Drought induced moisture stress in seedlings and significantly affected $A, E, g_{\mathrm{s}}$, and $\Psi_{\mathrm{L}}$ (Fig. 1, Tab. III). While WW plants maintained relatively stable $\Psi_{\mathrm{L}}$, values declined in seedlings in the three moisture stress treatments during the drought phase (Fig. 1D). Compared with WW plants, $\Psi_{\mathrm{L}}$ was reduced (i.e., increased stress) during the drought phase by $-0.4,-0.7$, and $-0.9 \mathrm{MPa}(P<0.0008)$ on 23 August and $-1.3,-1.5$, and $-1.8 \mathrm{MPa}(P<0.0001)$ by 4 September in respective LMS, MMS, and HMS seedlings (Fig. 1D, Tab. II). During the recovery phase after resumption of irrigation, $\Psi_{\mathrm{L}}$ increased for all treatments on 19 September and remained relatively stable thereafter (Fig. 1D). Photosynthetic assimilation declined from 23 August to 4 September during the drought phase, increased during the recovery phase after resumption of irrigation until 26 September, and then decreased by 25 October in conformity with the phenological stage of growth decline in northern red oak (Fig. 1A). The decline in $A$ during the drought phase intensified with increasing moisture stress $(P<0.0001$, Fig. 1A, Tab. II). During the recovery phase, $A$ steadily increased in LMS, MMS, and HMS treatments until 26 September, then declined thereafter. However, $A$ in HMS seedlings never reached the level of WW seedlings during the recovery period. Trends in $E$ (Fig. 1B) and $g_{\mathrm{s}}$ (Fig. 1C) were similar to those observed for $A$ during the drought and recovery phases.

The general trend of decrease, increase, and then decline in $A, E$, and $g_{\mathrm{s}}$ found in this study indicates the relatedness of these parameters. Strong positive linear relationships were detected between $g_{\mathrm{s}}, A$, and $E$ in our study (i.e., $g_{\mathrm{s}}$ and $E$ explained 86 and $91 \%$, respectively, of the variation in $A ; g_{\mathrm{s}}$ accounted for $97 \%$ of the variation in $E$ ).

\subsection{Influence of root volume on seedling physiological responses}

Seedling $R v$ significantly affected $A, E, g_{\mathrm{s}}$, and $\Psi_{\mathrm{L}}$ (Fig. 2, Tab. II). Plants with larger $R v$ experienced the highest water deficit (data pooled across moisture stress treatments) during the drought phase. For example, RvC1 was the least stressed $\left(\Psi_{\mathrm{L}}=-1.0 \mathrm{MPa}\right)$ while RvC4 was the most stressed $\left(\Psi_{\mathrm{L}}=\right.$ $-3.3 \mathrm{MPa}$ ) treatment by 4 September (Fig. 2D). There was a general decline in $A$ in all $\mathrm{RvC}$ treatments during the drought phase, especially for RvC4 (Fig. 2A). Although all RvC treatments had similar transpiration rates on 23 August (i.e., 27, 49, and $71 \mathrm{~d}$ after discontinuation of irrigation for the LMS, MMS, and HMS treatments, respectively), differences became significant $(P<0.0077)$ by 4 September (Fig. 2B, Tab. II). Compared with $\mathrm{RvC} 4, E$ was 5, 20, and 59\% higher in respective $\mathrm{RvC} 3, \mathrm{RvC} 2$, and $\mathrm{RvC} 1$ treatments on 4 September during the drought phase, and 8, 38, and 31\% higher on 19 September during the recovery phase (Fig. 2B). Values of $E$ for all treatments peaked on 19 September during the recovery phase after resumption of irrigation and declined thereafter (Fig. 2B). Values for $g_{\mathrm{s}}$ also differed $(P<0.0394)$ between treatments on 4 September during the drought phase with $g_{\mathrm{s}}$ about 2 fold higher in $\mathrm{RvC} 1$ relative to $\mathrm{RvC} 4$ plants (Fig. 2C). During the recovery phase, $g_{\mathrm{s}}$ in all treatments increased on 26 September and then declined to lower levels by 25 October (Fig. 2C).

Seedling RvC by moisture stress interactions were generally significant for physiological parameters during the drought phase (i.e., 23 August through 4 September) and nonsignificant thereafter during the recovery phase (Tab. II). Significant interaction effects were indicated by reduced $A, g_{\mathrm{s}}$, and $E$ with increasing $R v$ under higher soil moisture stress conditions. On 23 August, for example, $A$ was 7.96, 9.86, 8.23, and $10.16 \mu \mathrm{mol} \mathrm{m} \mathrm{m}^{-2} \mathrm{~s}^{-1}$ for respective $\mathrm{RvC1}, \mathrm{RvC} 2$, $\mathrm{RvC} 3$, and $\mathrm{RvC} 4$ treatments in the WW treatment. In the water stress treatments, $A$ declined much more rapidly for large RvC seedlings. In the LMS treatment, for example, $A$ was $6.35,8.82,6.09$, and $3.08 \mu \mathrm{mol} \mathrm{m} \mathrm{m}^{-2} \mathrm{~s}^{-1}$ for respective $\mathrm{RvC1}$, $\mathrm{RvC} 2, \mathrm{RvC} 3$, and $\mathrm{RvC} 4$ treatments. In the MMS treatment, $A$ was $6.31,4.34,6.50$, and $1.66 \mu \mathrm{mol} \mathrm{m} \mathrm{m}^{-2} \mathrm{~s}^{-1}$ for respective $\mathrm{RvC} 1, \mathrm{RvC} 2, \mathrm{RvC} 3$, and $\mathrm{RvC} 4$ treatments. In the HMS treatment, $A$ was $2.10,3.50,0.90$, and $0.74 \mu \mathrm{mol} \mathrm{m} \mathrm{m}^{-2} \mathrm{~s}^{-1}$ for respective $\mathrm{RvC} 1, \mathrm{RvC} 2, \mathrm{RvC} 3$, and $\mathrm{RvC} 4$ treatments. Similar trends were found for $E, g_{\mathrm{s}}$, and $\Psi_{\mathrm{L}}$ for this sampling date and on 4 September (data not shown). This implies that increasing moisture stress more negatively affected performance of larger RvC seedlings. 

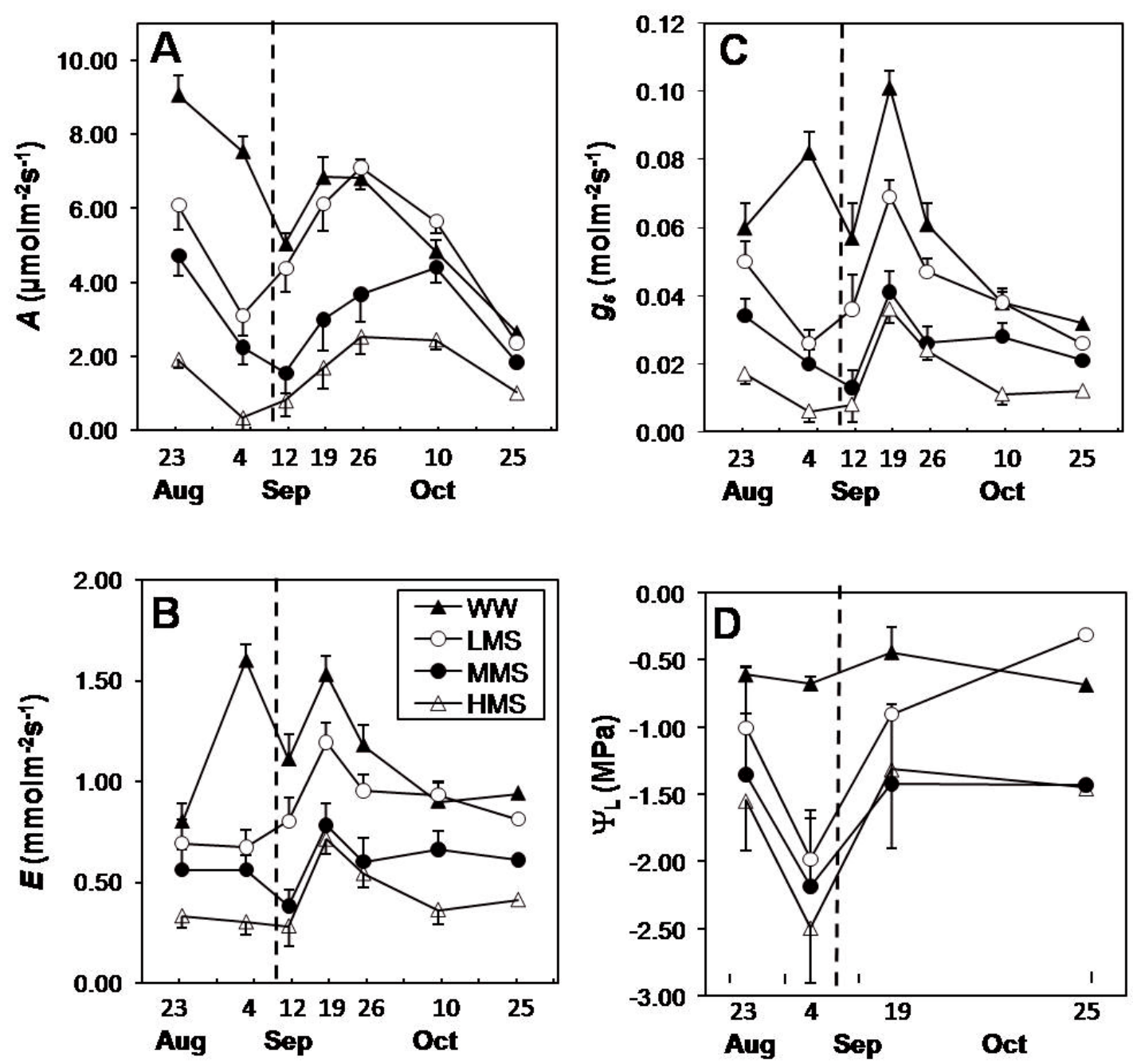

Figure 1. Variations in (A) photosynthetic assimilation $(A),(\mathrm{B})$ transpiration rates $(E),(\mathrm{C})$ stomatal conductance $\left(g_{\mathrm{s}}\right)$, and $(\mathrm{D})$ predawn leaf xylem water potential $\left(\Psi_{\mathrm{L}}\right)$ in northern red oak seedlings grown under well watered conditions (WW), low moisture stress (LMS), medium moisture stress (MMS), and high moisture stress (HMS) as induced by drought under greenhouse environments. Bars represent standard error of the mean. The dashed line separates period during which drought was imposed from resumption of irrigation.

\subsection{Effects of drought and seedling root volume on plant growth}

Moisture stress reduced seedling growth except for height $(P<0.1507)$ during the drought phase (Figs. 3 and 4, Tab. III). Growth parameters remained lower following the recovery phase for plants that experienced significant water deficits. For example, plant dry mass was $110-134 \%$ greater in WW vs. HMS seedlings (Fig. 3, Tab. III). More growth was allocated to roots than shoots under increasing moistures stress, with shoot:root dry mass ranging from 1.31 (WW) to 1.10 (HMS). Compared to HMS treatments, plant fresh mass was 91, 213, and $465 \%$ (drought phase) and 37, 139, and $158 \%$ (recovery phase) higher in respective MMS, LMS, and WW plants (Fig. 3, Tab. III). Similar comparisons for Rv growth were 3, 7 , and 24 times higher (drought phase) and about 2, 3, and 3 fold higher (recovery phase) in respective MMS, LMS, and
WW vs. HMS treatments. Seedling leaf area $\left(A_{\mathrm{L}}\right)$ and number of leaves were significantly reduced by drought (Fig. 4, Tab. III); the former was reduced by about $163 \%$ in HMS vs. WW plants.

Seedling $R v$ affected height, dry mass production, leaf area, and number of leaves at the sampling following the end of the drought phase (Figs. 4 and 5, Tab. III). For example, relative to $\mathrm{RvC} 1$, plant dry mass was greater by $24 \%$ in $\mathrm{RvC} 2,52 \%$ in $\mathrm{RvC} 3$, and $161 \%$ in $\mathrm{RvC} 4$ (Fig. 5). Leaf area increased from 32 to $81 \%$ and leaf numbers increased from 37 to $163 \%$ in respective $\mathrm{RvC} 2$ and $\mathrm{RvC} 4$ compared to RvC1 (Fig. 4, Tab. III). However, differences among RvC treatments were not statistically different for morphological parameters at the sampling following the recovery phase, except for height growth (Fig. 5, Tab. III). 

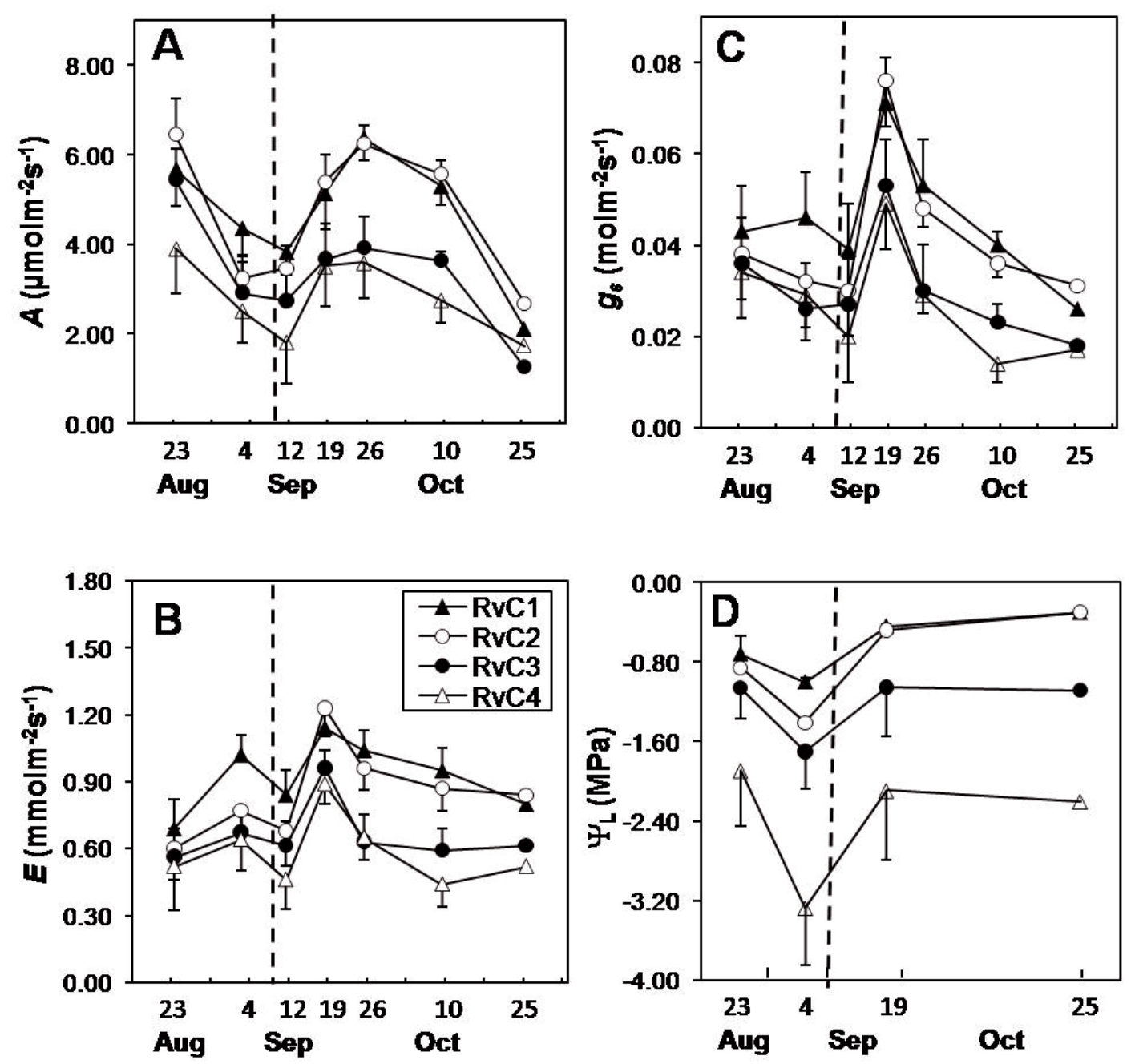

Figure 2. Variations in (A) photosynthetic assimilation $(A)$, (B) transpiration rates $(E)$, (C) stomatal conductance $\left(g_{\mathrm{s}}\right)$, and $(\mathrm{D})$ predawn leaf xylem water potential $\left(\Psi_{\mathrm{L}}\right)$ in northern red oak seedlings as influenced by root volume category (RvC), ranging from the smallest $(\mathrm{RvC} 1)$ to the largest (RvC4). Bars represent standard error of the mean. The dashed line separates period during which drought was imposed from resumption of irrigation.

\section{DISCUSSION}

\subsection{Seedling physiological and morphological responses to drought}

Drought induced moisture stress as indicated by lower $\Psi_{\mathrm{L}}$ in seedlings (Fig. 1). Water deficits were also associated with reduced $A, E$, and $g_{\mathrm{s}}$, and growth consistent with results of others (Blake and Filho, 1988; Apostol et al., 2009). This confirms that moisture stress is an important factor causing transplant shock. These observations concur with results reported for Engelmann spruce (Burdett et al., 1984) and Douglas-fir (Haase and Rose, 1993) seedlings. Transplant shock was also indicated by reduced leaf area (Fig. 4B) consistent with results for loblolly pine (Pinus taeda L.) (Teskey et al., 1987), Douglas-fir (Haase and Rose, 1993), and northern red oak (Struve and Joly, 1992) seedlings. The mild water stress in WW plants following transplant indicates that there is a time lag during which transplanted seedlings must re-establish rootsoil contact for resource exploitation, and may also infer temporary impairment of root function (Burdett, 1990; Sands, 1984). This also suggests that timing planting to minimize exposure to stressful environmental conditions during the several weeks following planting will improve seedling establishment success.

Increased A with increasing $g_{\mathrm{s}}$ may be associated with improved intercellular $\mathrm{CO}_{2}$ exchange and carbon fixation at higher $g_{\mathrm{s}}$ (Dixon et al., 1995). This may also suggest that $A$ and $g_{\mathrm{s}}$ may be co-regulated in response to water stress (Weber and Gates, 1990). Strong positive linear relationships were detected between $g_{\mathrm{s}}, A$, and $E$ in our study as similarly observed for mature almond (Prunus dulcis (Mill.)) trees (Romero et al., 2004). In contrast, water deficits may decrease $A$ directly by affecting the metabolic and photochemical process in the leaf or indirectly through stomatal closure leading to cessation of 

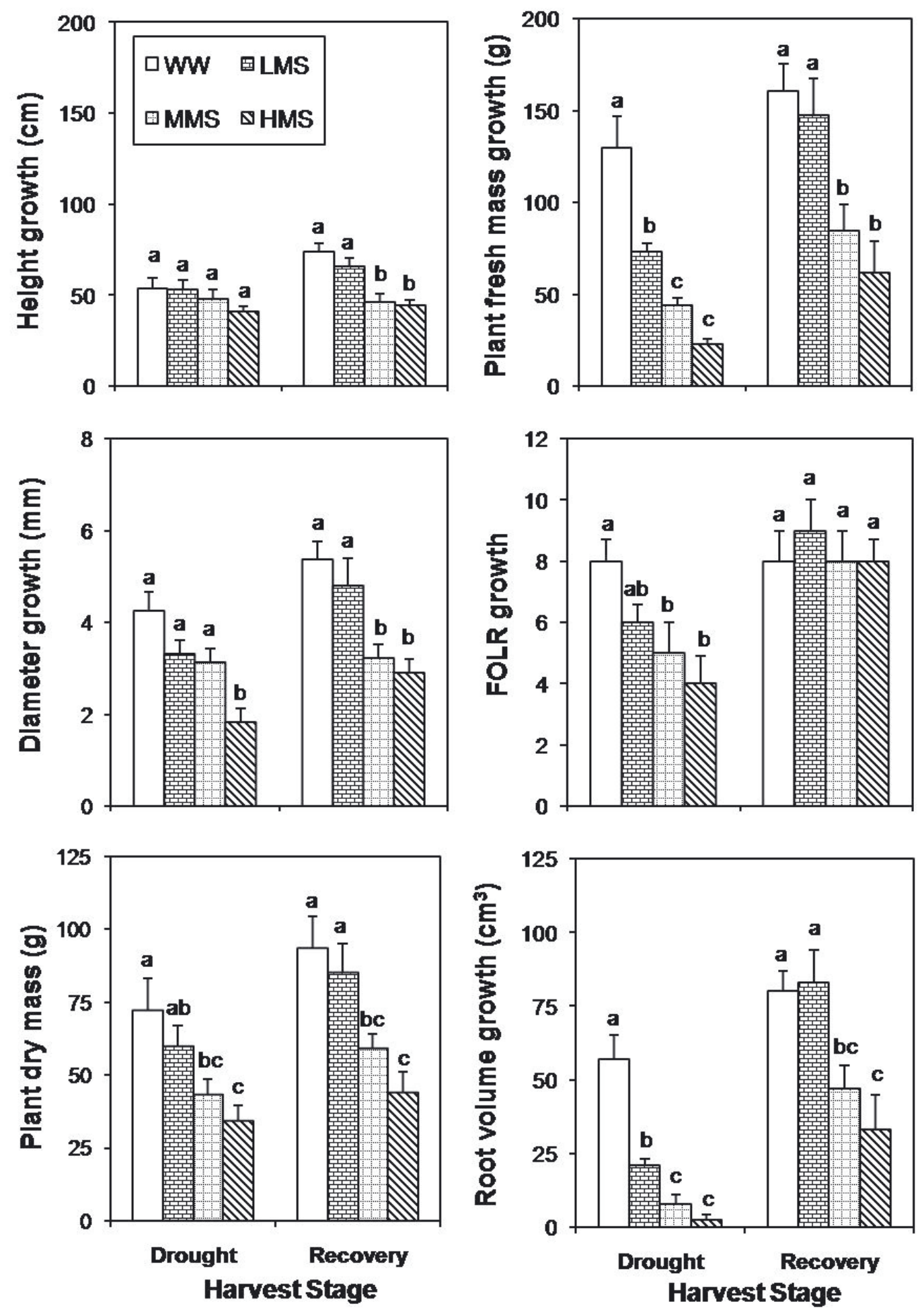

Figure 3. Northern red oak seedling growth sampled at the end of the drought and recovery (after resumption of irrigation) phases under well watered conditions (WW), low moisture stress (LMS), medium moisture stress (MMS), and high moisture stress (HMS). Bars represent standard error of the mean. 

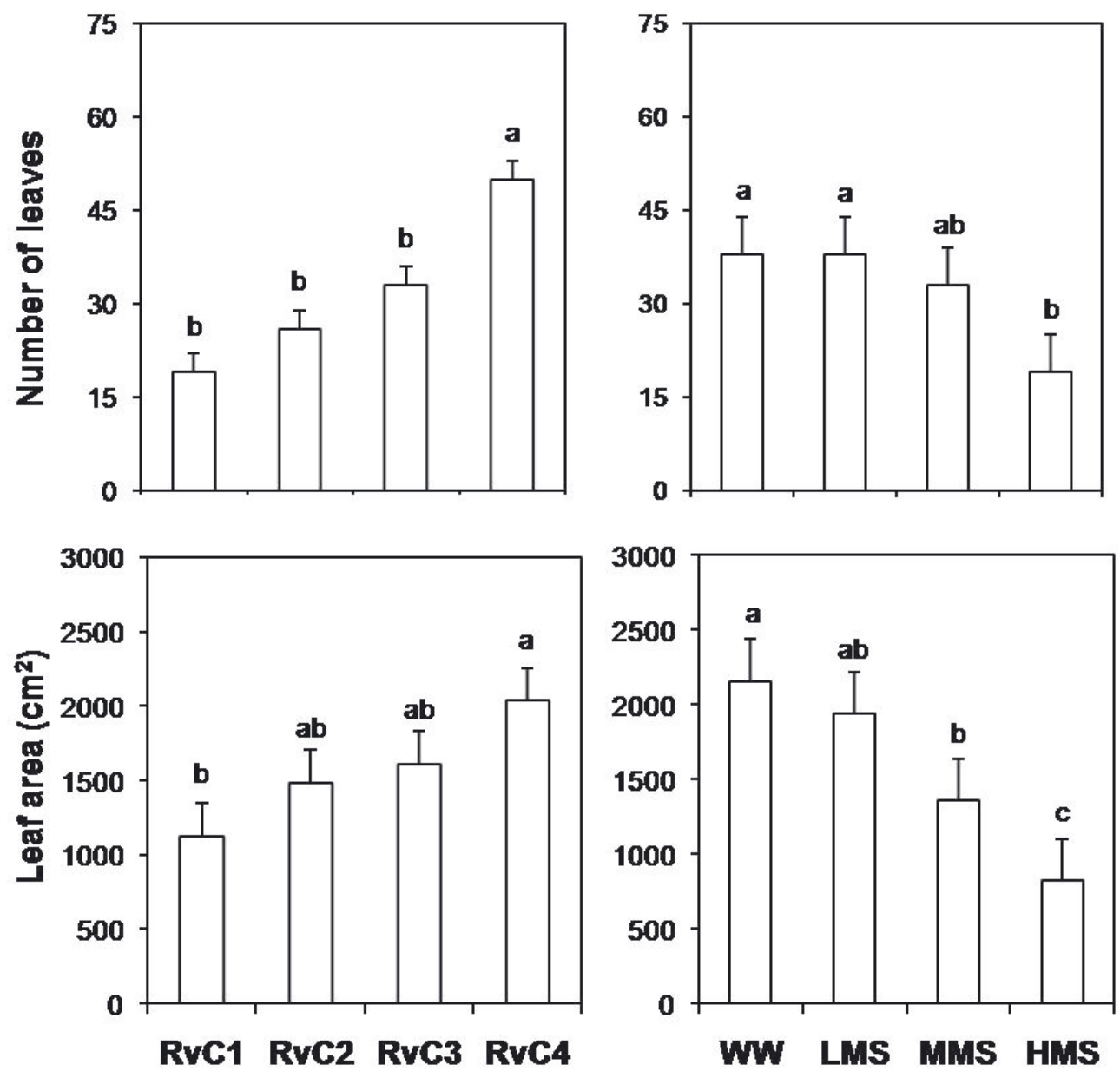

Figure 4. Northern red oak seedling leaf numbers and leaf area at the end of the drought phase as influenced by (left) root volume category $(\mathrm{RvC})$, ranging from the smallest $(\mathrm{RvC} 1)$ to largest $(\mathrm{RvC} 4)$ and (right) grown under well watered conditions (WW), low moisture stress (LMS), medium moisture stress (MMS), and high moisture stress (HMS). Bars represent standard error of the mean.

leaf growth and consequent decreased leaf area. For instance, as $\Psi_{\mathrm{L}}$ decreases, $g_{\mathrm{s}}$ also declines (Meinzer, 1982) and $A$ is directly related to $g_{\mathrm{s}}$ (Hinckley et al., 1978). Reductions in $A$ and $g_{\mathrm{s}}$ in response to severe water stress were reversible (though still evident in highly stressed seedlings), suggesting that extended drought as applied in our study did not cause permanent damage (i.e., to permanent wilting point) to plant tissues. Thus, rapid (i.e., within $10 \mathrm{~d}$ in our study) recovery of $\Psi_{\mathrm{L}}$ and $A$ after water deficits may reflect adaptive drought resistance in northern red oak seedlings.

\subsection{Root volume alters seedling physiology and growth responses}

Planting shock, caused by water or nutrient stress, may lead to root growth being limited by lack of current photosynthate or vice versa (Burdett, 1990, Grossnickle, 2000). Therefore, rapid root growth after planting is important to exploit water from surrounding soil, which will help establish a proper water balance in seedlings (Grossnickle, 2005). As demonstrated here, increased root growth in LMS plants is one mechanism to explain the ability of these seedlings to resist transplant shock as indicated by higher $\Psi_{\mathrm{L}}$.

Seedlings with large initial $R v$ have higher root growth potential (Carlson, 1986; Grossnickle, 2005), tend to better tolerate transplant shock over time (Haase and Rose, 1993), and may have more rapid early growth rates (Rose et al., 1991a; 1991b). Despite proposed advantages of planting large $R v$ seedlings, evidence suggests that large $R v$ does not mitigate drought avoidance in bareroot seedlings immediately following transplanting. No differences were found in $\Psi_{\mathrm{L}}$ at 95 or $115 \mathrm{~d}$ in Douglas-fir seedlings graded into different $R v$ classes and transplanted into pots (Haase and Rose, 1993). Similarly, Jacobs et al. (2004a) reported no significant differences in $\Psi_{\mathrm{L}}$ between RvC for Douglas-fir seedlings following field transplant. Contrary to above results, we observed that northern red oak seedlings with larger initial $R v$ were less able to mitigate effects of drought following transplant, as indicated by lower $\Psi_{\mathrm{L}}$ values (Fig. 2D). Furthermore, it has been shown that seedling $R v$ is positively correlated with leaf area (Carlson and 

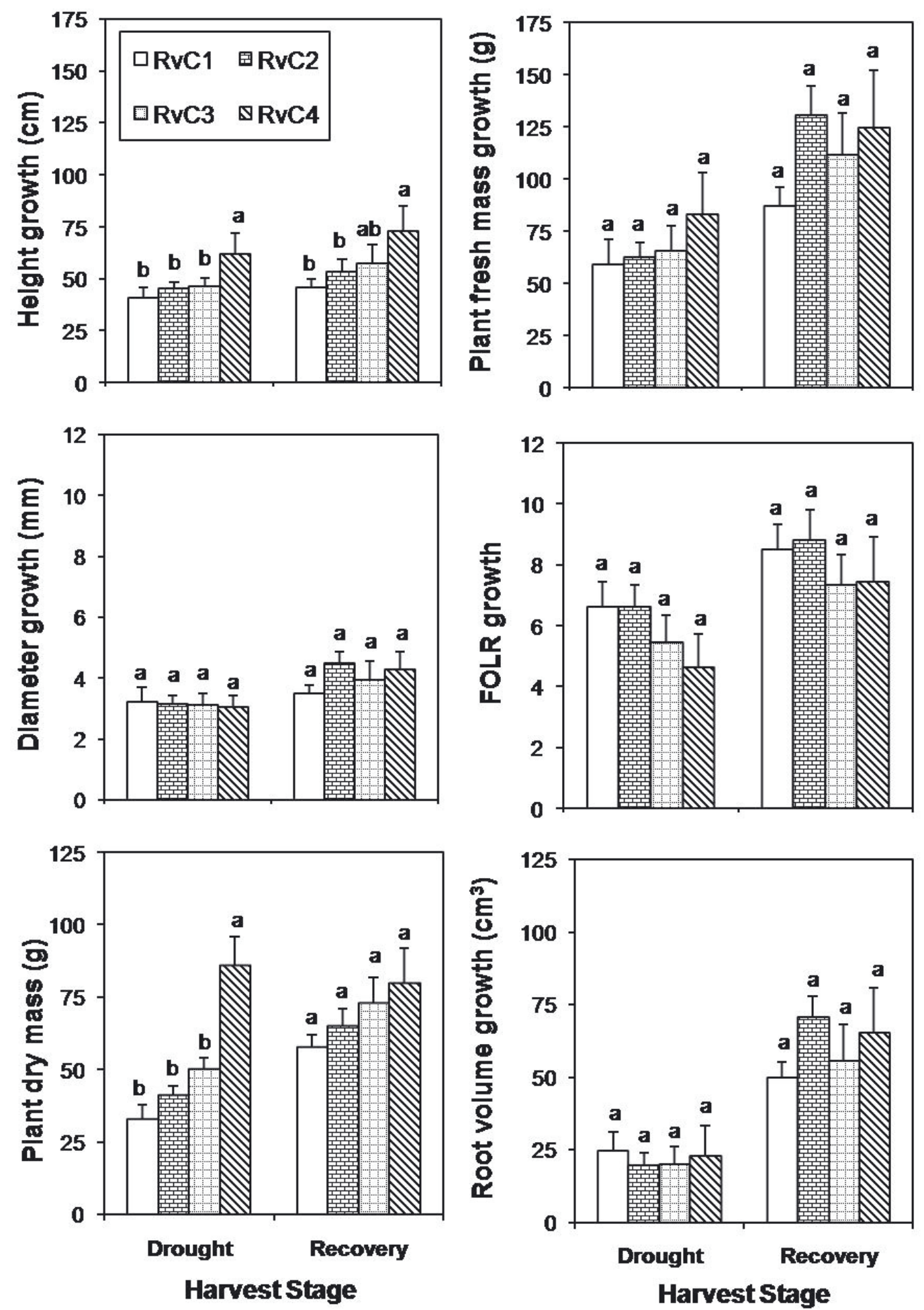

Figure 5. Northern red oak seedling growth sampled at the end of the drought and recovery (after resumption of irrigation) phases as influenced by root volume category $(\mathrm{RvC})$, ranging from the smallest $(\mathrm{RvC} 1)$ to the largest $(\mathrm{RvC} 4)$. Bars represent standard error of the mean. 
Miller, 1990). We also found that larger $R v$ plants were associated with greater transpiring area (Fig. 4A), which induced severe water deficits by lowering $\Psi_{\mathrm{L}}$ to $-3.3 \mathrm{MPa}$ in these plants (Fig. 2). Depressed $A, E$, and $g_{\mathrm{s}}$ with increasing $R v$ under drought conditions demonstrates that seedlings with larger initial $R v$ may be more prone to transplant shock especially on sites subject to summer drought (Blake, 1983; Grossnickle, 1988).

One mechanism to alleviate transplant shock is greater growth allocation to roots relative to shoots under stress as found in this study. Such a growth allocation strategy is a wellknown adaptive mechanism by which plants respond to limitations of belowground resources (Teskey et al., 1987). In addition, reduced leaf area as observed in smaller $\mathrm{RvC}$ seedlings (Fig. 4) is yet another drought avoidance mechanism that alleviates transplant shock under high moisture stress (Struve and Joly, 1992). Hence, smaller transpiring leaf area as observed in $\mathrm{RvC} 1$ seedlings may increase survival and growth potential on droughty sites.

Large $\mathrm{RvC}$ seedlings with greater transpirational area may be at an earlier disadvantage on droughty sites because of anticipated increased $E$ (Haase and Rose, 1993). However, our results do not support increased $E$ in $\mathrm{RvC} 4$ seedlings (Figs. 2 and $4 \mathrm{~A}$ ). In fact, $\mathrm{RvC} 4$ seedlings responded to severe water deficits by limiting stomatal responses that resulted in reduced $E$ (Fig. 2), demonstrating sensitivity of these plants to moisture stress. Furthermore, Haase and Rose (1993) contend that even if an earlier disadvantage were to occur in $\mathrm{RvC} 4$ plants due to higher $E$, the effect may be short term, during which time seedling root systems re-establish soil contact. Higher survival and growth of ponderosa pine (Pinus ponderosa C. Lawson) and Douglas-fir seedlings with larger initial $R v$ relative to those with smaller $R v$ after two growing seasons on harsh sites was attributed to greater access of larger root systems to limited water and nutrients (Rose et al., 1991a; 1991b). In contrast to the above scenarios, Blake and Filho (1988) reported that seedling size of Eucalyptus spp. was inversely related to $g_{\mathrm{s}}$, and hence $E$. In our study, smaller seedlings were also associated with the highest $g_{\mathrm{s}}$ while larger seedlings had the lowest $g_{\mathrm{s}}$ (Fig. 2), consistent with these results.

Although moisture stress limited $A$ in large $\mathrm{RvC}$ seedlings, growth was generally similar among $\mathrm{RvC}$ treatments (excepting greater height growth in $\mathrm{RvC} 4$ plants). Thus, greater $A$ at the whole plant level associated with larger leaf area and numbers may be more important than $A$ in explaining growth response in large $\mathrm{RvC}$ plants (Fig. 4A). This response may correspond to that of cork oak (Quercus suber L.) seedlings, in which increased specific leaf area associated with shading under water limiting conditions resulted in equivalent biomass production despite reductions in instantaneous photosynthetic rates (Puértolas et al., 2008). In addition, $\mathrm{N}$ and carbohydrate reserves are essential for new growth development before significant root uptake and photosynthesis (Salifu et al., 2008; Sloan and Jacobs, 2008). Therefore, higher internal nutrient reserves or stored carbohydrates may have contributed to growth in large plants. As a result, planting seedlings with high internal nutrient or carbohydrate reserves may improve field performance because reserves function as immediate sources to meet ongoing growth demand until developing roots can exploit soil for growth resources. The significant moisture stress $\times R v$ interactions (Tab. III) reflected reduced performance of $\mathrm{RvC} 4$ seedlings on MMS and HMS conditions, suggesting that large stock should be targeted for sites with higher moisture availability. Strict stomatal regulation, increased root growth, root/shoot balance, and reduced leaf area appear to be some of the most effective mechanisms by which northern red oak seedlings can adapt to dry environments.

\section{CONCLUSIONS}

Drought induced physiological water deficit in northern red oak seedlings, which was more severe for larger RvC plants. This suggests that large initial root system size does not confer drought avoidance in bareroot northern red oak seedlings, as was similarly reported for Douglas-fir seedlings (Haase and Rose, 1993; Jacobs et al., 2004a), and that large planting stock should be targeted for sites with relatively higher soil moisture availability. Transplant shock in northern red oak seedlings was implicated by reduced $\Psi_{\mathrm{L}}, A, E$, and growth. Rapid recovery of $\Psi_{\mathrm{L}}$, and $A$ after resumption of irrigation reflects adaptive drought resistance in northern red oak seedlings. Greater growth allocation to roots relative to shoots, increased root growth, reduced leaf area, and strict stomatal regulation seem to be the most effective mechanisms by which northern red oak seedlings resist moisture stress.

Controlled environment studies of seedling drought resistance have inherent limitations when extrapolating results to potential field responses. For example, root system proliferation is limited to a fixed soil volume in containers, which may alter soil-water physics. This type of experimentation under conditions free of potentially confounding ambient circumstances, however, is common in modern reforestation sciences (e.g., Haase and Rose, 1993; Apostol et al., 2009) and a necessary prerequisite to understanding mechanisms for drought resistance responses following field transplant. Use of relatively large pots (e.g., $12 \mathrm{~L}$ in this study) helps to better simulate field conditions, yet results must be interpreted with caution when making operational recommendations. Nevertheless, our results support those of Haase and Rose (1993) that selection of particular root system size for transplanting on sites of known moisture availability may be important to improve early growth and vigor of plantations. This knowledge is essential to help target seedlings with specific root volume to suitable planting environments for improved seedling establishment, which will enhance early plantation development.

Acknowledgements: Financial assistance was provided by USDA Forest Service (State and Private Forestry), the Hardwood Tree Improvement and Regeneration Center, and the Department of Forestry and Natural Resources, Purdue University. Indiana Department of Natural Resources Vallonia Nursery donated seedlings. We acknowledge the technical and/or lab assistance of P. Alzugaray, R. Eddy, J. McKenna, and A. Ross-Davis. Gilbert Aussenac and two anonymous referees provided helpful comments that improved the manuscript. 


\section{REFERENCES}

Anderson V.L. and McLean R.A., 1974. Design of experiments: a realistic approach, Marcel Decker Inc., New York.

Apostol K.G., Jacobs D.F., and Dumroese R.K., 2009. Root desiccation and drought stress responses of bareroot Quercus rubra seedlings treated with a hydrophilic polymer root dip. Plant Soil 315: 229-240.

Blake T.J., 1983. Transplanting shock in white spruce: effect of cold storage and root pruning on water relations and stomatal conditioning. Physiol. Plant. 57: 210-216.

Blake T.J., and Filho W.S., 1988. Drought tolerance, growth partitioning and vigor in eucalyptus seedlings and rooted cuttings. Tree Physiol. 4: $325-335$.

Burdett A.N., 1990. Physiological processes in plantation establishment and development of specification for forest planting stock. Can. J. For. Res. 20: 415-427.

Burdett A.N., Herring L.J., and Thompson C.F., 1984. Early growth of planted spruce. Can. J. For. Res. 14: 644-651.

Carlson W.C., 1986. Root system consideration in the quality of loblolly pine seedlings. South. J. Appl. For. 10: 87-92.

Carlson W.C. and Miller D.E., 1990. Target seedling root system size, hydraulic conductivity and water use during seedling establishment. In: R. Rose, S.J. Camphell, and T.D. Landis (Eds.), Target seedling symp: Proc. Combined meeting of the Western For. Nursery Assocs. USDA For. Serv. Gen. Tec. Rep. RM-200. p. 53-65.

Dixon M., Le Thiec D., and Garrec J.P., 1995. The growth and gas exchange response of soil-planted Norway spruce [Picea abies L. (Karst)] and red oak [Quercus rubra L.] exposed to elevated $\mathrm{CO}_{2}$ and naturally occurring drought. New Phytol. 129: 265-273.

Grossnickle S.C., 1988. Planting stress in newly planted jack pine and white spruce. 2. Changes in tissue water potential components. Tree Physiol. 4: 85-97.

Grossnickle S.C., 2000. Ecophysiology of Northern Spruce Species: The performance of planted seedlings, NRC Research Press, Ottawa, Ontario, Canada. 409 p.

Grossnickle S.C., 2005. Importance of root growth in overcoming planting stress. New For. 30: 273-294.

Haase D.L. and Rose R., 1993. Soil moisture stress induces transplant shock in stored and un-stored $2+0$ Douglas-fir seedlings of varying root volumes. For. Sci. 39: 275-294.

Hinckley T.M., Austin R.G., Aubuchon R.R., Metcalf C.L., and Roberts J.E., 1978. Leaf conductance and photosynthesis in four species of the oak-hickory forest type. For. Sci. 24: 73-84.

Jacobs D.F., 2003. Nursery production of hardwood seedlings. In Planting and care of fine hardwood seedlings, Hardwood tree improvement and regeneration center, West Lafayette, IN, USA, 8 p.

Jacobs D.F., Rose R., Haase D.L., and Alzugaray P.O., 2004a. Fertilization at planting impairs root system development and drought avoidance of Douglas-fir (Pseudotsuga menziesii) seedlings. Ann. For. Sci. 61: 643-651.

Jacobs D.F., Ross-Davis A.L., and Davis, A.S., 2004b. Establishment success of conservation tree plantations in relation to silvicultural practices in Indiana, USA. New For 28: 23-36.

Jacobs D.F., Salifu K.F., and Seifert J.R., 2005.Relative contribution of initial root and shoot morphology in predicting field performance of hardwood seedlings. New For 30: 295-311.
Johnson P.S., Novinger S.L., and Mares W.G., 1984. Root, shoot, and leaf area growth potentials of northern red oak planting stock. For. Sci. 30: 1017-1026.

Jones M.M., Turner N.C., and Osmond C.B., 1981. Mechanisms of drought resistance. In: Paleg L.G. and Aspinal D. (Ed.), The physiology and biochemistry of drought resistance in plants, Academic press, Sydney, pp. 15-35.

Levitt J., 1972. Responses of plants to environmental stresses, Academic Press, New York, 697 p.

Meinzer F.C., 1982. The effect of vapor pressure on stomatal control of gas exchange in Douglas-fir saplings. Oecologia 54: 236-242.

Puértolas P., Pardos M., Dolores Jiménez M., Aranda I., and Alberto Pardos J., 2008. Interactive responses of Quercus suber L. seedlings to light and mild water stress: effects on morphology and gas exchange traits. Ann. For. Sci. 65: 611.

Romero P., Navarro J.M., Garcia F., and Ordaz P.B., 2004. Effect of regulated deficit irrigation during the pre-harvest period on gas exchange, leaf development and crop yield of mature almond trees. Tree Physiol. 24: 303-312.

Rose R., Atkinson M., Gleason J., and Sabin T., 1991a. Root volume as a grading criterion to improve field performance of Douglas-fir seedlings. New For. 5: 195-209.

Rose R., Gleason J., Atkinson M., and Sabin T., 1991b. Grading ponderosa pine seedlings for outplanting according to their root volume. West. J. Appl. For. 6: 11-15.

Salifu K.F., Apostol K.G., Jacobs D.F., and Islam M.A., 2008. Growth, physiology, and nutrient retranslocation in nitrogen-15 fertilized Quercus rubra seedlings. Ann. For. Sci. 65: 101.

Sander I.L., 1990. Northern red oak (Quercus rubra L.). In Silvics of North America: 2. Hardwoods. Tech. coords. R.M. Burns, and H.H. Barabara. Agriculture Handbook 654. USDA, For. Ser., Washington, DC, Vol. 2, 877 p.

Sands R., 1984. Transplanting stress in radiata pine. Aust. For. Res. 14: $67-72$.

Sloan J.L. and Jacobs D.F., 2008. Carbon translocation patterns associated with new root proliferation during episodic growth of transplanted Quercus rubra seedlings. Tree Physiol. 28: 1121-1126.

Struve D.K., 1990. Root regeneration in transplanted deciduous nursery stock. HortSci. 25: 266-270.

Struve D.K. and Joly R.J., 1992. Transplanted red oak seedlings mediate transplant shock by reducing leaf surface area and altering carbon allocation. Can. J. For. Res. 22: 1441-1448.

Teskey R.O., Bongarten B.C., Cregg B.M., Dougherty P.M., and Hennessey T.C., 1987. Physiology and genetics of tree growth response to moisture and temperature stress: an examination of the characteristics of loblolly pine (Pinus taeda L.). Tree Physiol. 3: $41-61$.

Vyse A., 1981. Growth of young spruce plantations in interior British Columbia. For. Chron. 57: 174-180.

Waters W.E., DeMars C.J. Jr., and Cobb F.W. Jr., 1991. Analysis of early mortality of Douglas-fir seedlings in postharvest plantings in Northwestern California. For. Sci. 27: 802-826.

Weber J.A. and Gates D.M., 1990. Gas exchange in Quercus rubra (northern red oak) during a drought: analysis of relations among photosynthesis, transpiration, and leaf conductance. Tree Physiol. 7: 215-225. 